\title{
IAMJ
}

INTERNATIONAL

AYURVEDIC

MEDICAL JOURNAL

\section{A CLINICAL STUDY ON THE MANAGEMENT OF STHAULYA BY TRIKATU CHURNA}

\author{
Ankur Saxena ${ }^{1}$, Sunil K Gupta ${ }^{2}$, Jolly Saxena ${ }^{3}$, Niranjan $S^{4}$ \\ ${ }^{1}$ Assistant Professor, P. G. Department of Rognidan, \\ ${ }^{2}$ Professor and H.O.D., P. G. Department of Rognidan, \\ ${ }^{3}$ Professor and H.O.D., P. G. Dept of Rasashastra and Bhaishajya Kalpana, \\ ${ }^{4}$ Professor and H.O.D., P. G. Department of Kayachikitsa, \\ Major S.D. Singh P.G. Ayurvedic Medical College and Hospital, Farrukhabad, Uttar Pradesh, India
}

Corresponding Author: drankursaxena.aug@gmail.com

https://doi.org/10.46607/iamj03p4052020

(Published online: July 2020)

Open Access

(C) International Ayurvedic Medical Journal, India 2020

Article Received: 05/06/2020 - Peer Reviewed: 25/007/2020 - Accepted for Publication: 27/07/2020

Check for updates

\begin{abstract}
Sthaulya / Atisthaulya in Ayurveda comes under the heading of Medoroga which results due to dysfunction of Meda Dhatvagni (factor responsible for nourishment / metabolism of Meda dhatu) and in modern parlance it is equated with Obesity due to its close similarities. It is the main cause for so many complications like Hypertension, Diabetes mellitus, Osteoarthritis, Infertility, Impotency etc. as well as psychological disturbances like anxiety, depression etc. Thus, the mortality and morbidity rate were high in obese persons compared to others. This shows the importance of the need for further researches of effective measures in the management of Sthaulya. Hence in the present study a clinical trial was carried out with Trikatu Churna in the management of Sthaulya (obesity) for 30 days. 30 patients were selected with diagnosis of Sthaulya out of which 24 completed the treatment. The study concluded with the positive results of Trikatu churna in reducing the signs and symptoms of Sthaulya.
\end{abstract}

Keywords: Sthaulya, Obesity, Trikatu Churna, Body Mass Index 


\section{INTRODUCTION}

Obesity is a disease of all age group within the people of high socio-economic status, specifically of Urban Communities. It is a complex, multi factorial disease which invites several pathological complications like Hypertension, Type 2 Diabetes mellitus, atherosclerosis, infertility, hepatic steatosis / fatty liver, endocrine abnormalities, obstetric complications, osteoarthritis of weight bearing joints, certain types of cancers, and possibly immunological impairment as well as it hampers the cosmetic value of the affected person. It has deleterious effects both on body and mind. Further, its description is available in Ashtaunindita Purusha Adhyaya of Charaka Samhita (chapter dedicated to 8 types of undesirable physiques where obese are criticized by society because of inappropriate body size). Rapid increase of prevalence rate of obesity suggests all branches of medicines to understand the etiology and pathogenesis of this disease as per the basic fundamental principles of concerned health. Obesity is one of the most serious public health problems of the $21^{\text {st }}$ century. It is a complex, multifactorial, and largely preventable disease, affecting, along with overweight, over a third of the world's population today ${ }^{1,2}$. If secular trends continue by 2030 an estimated $38 \%$ of the world's population will be overweight and another $20 \%$ will be obese ${ }^{3}$. Some recent WHO (as updated on 01.04.2020) global estimates follow: ${ }^{4}$

WHO declared obesity as global epidemic giving rise to new term "Globesity". In 2016, more than 1.9 billion adults aged 18 years / older were overweight. Of these over 650 million adults were obese. In 2016, $39 \%$ of adults aged 18 years and over $(39 \%$ of men and $40 \%$ of women) were overweight. Overall, about $13 \%$ of the world's adult population (11\% of men and $15 \%$ of women) were obese in 2016 . The worldwide prevalence of obesity nearly tripled between 1975 and 2016. In 2016, an estimated 41 million children under the age of 5 years were overweight or obese. Once considered a high-income country problem, overweight and obesity are now on the rise in low- and middle-income countries particularly in urban countries. The most common cause of obesity is excess calorie intake coupled with physical inactivity usually seen in modern sedentary lifestyle. Obesity describes a weight of $120 \%$ or above $e^{5}$. It is a state of excess adipose tissue mass ${ }^{6}$. An abnormal growth of adipose tissue due to an enlargement of fat cell size (Hypertrophic obesity) or an increase in fat cell number (Hyperplastic obesity) or combination of both is called obesity $^{7}$. Body Mass $\operatorname{Index}^{8}$ is considered as the standard measure for calculating Obesity. BMI is calculated by taking an individual weight (in $\mathrm{kg}$ ) and dividing it by his or her height (in meters square). BMI between 25 and $29.9 \mathrm{~kg} / \mathrm{m}^{2}$ is called overweight and a BMI greater than $30 \mathrm{~kg} / \mathrm{m}^{2}$ is called obese. There are many therapies and drugs which are available in Ayurveda and Modern science for the management of Sthaulya. But there are no promising results available. In modern medical science its management aspect remains symptomatic with troublesome side effects. Today it is a need to find the drug, which is cost effective, easily available and has excellent results with zero side effects. In Ayurveda, the main line of treatment explained is Apatarpana (depletion), ${ }^{9}$ where in ushna (hot potency), teekshna (penetrating), kaphahara, medohara drugs are administered.

Aim and Objectives: To evaluate the role of Trikatu Churna on Sthaulya.

\section{Materials and Methods:}

Selection of Subject - 30 patients attending the Kayachikitsa O.P.D. \& I.P.D. of Major S.D. Singh P.G. Ayurvedic Medical College and Hospital, Farrukhabad (U.P.) diagnosed with Sthaulya were selected in the age group of 20 years to 50 years irrespective of race, caste and religion. Written and informed consent of patients was taken before trial. 24 participants completed the treatment course out of 30 subjects and 6 cases were LAMA. These 24 cases were only considered for the calculation of effect of therapy.

Type of Study: It was an open trial method with Single group only.

Selection of Trial Drug: In the present research work an Ayurvedic classical drug Trikatu churna was prepared and assessed for its efficacy in Sthaulya roga. This drug has also been mentioned by Sushruta Su- 
trasthana $^{10}$ in chapter $38 / 59$ and by Sharangdhar Madhyama Khanda ${ }^{11}$ in chapter 6/12.

Preparation of Trial drug - The ingredients were obtained from local market and verified by Dravyaguna department. The drugs were then, cleaned, washed and dried. These were then subjected to powder in machine separately and then mixed together to form Trikattu Churna. Processing of drugs was done in college Pharmacy under the supervision of experts. Dosage Schedule: Trikatu churna in the dose of $3 \mathrm{gms}$ twice a day with lukewarm water as anupana was administered for 30 days.

\section{Inclusion Criteria:}

- Patients having three or more cardinal symptoms of obesity.

- $\quad$ BMI $>30$

- Male patients with waist hip ratio (WHR) $>1 \&$ females WHR $>0.85$.

\section{Exclusion Criteria:}

- Patient whose age $>50$ yrs and $<20$ yrs.

- The obese patients suffering from specific conditions like Diabetes mellitus, hypothyroidism, cardiovascular disease, Cushing's syndrome, severe hypertension, Garbhini (pregnant women), endogenous obesity and from other such disease in which the patients cannot do his routine physical activity can be excluded.

- Patients having previous surgical intervention for Sthaulya.

- Patients not fulfilling inclusion criteria.

\section{Criteria for assessment:}

The assessment was done on the basis of following Subjective parameters and Objective parameters. The Subjective parameters were Daurgandhya (foul smell), Kshudra shwas (breathlessness), Angagaurava (heaviness of the body), Atikshudha (increased appetite), Atipipasa (excess thirst), Sphik chalatva (movements of buttocks), Udara chalatva (abdomen movements), Stana chalatva (breast movement), Utsaha Hani / Alasya (Reduced interest / Laziness), Alpa vyayam (Exercises), Snigdhagatrata (Oily skin) and Angashaithilya (flabbiness in the body). The Objective parameters were Body weight, Body mass index (B.M.I.), Anthropometrics (Measuring skin fold thickness by using Vernier calipers) of Triceps and Biceps muscles. Measurements are taken at various body parts namely: Chest, Abdomen, Hips, Mid arm and Mid-thigh.

\section{Subjective criteria for assessment:}

A multidimensional scoring pattern was adopted for the above-mentioned symptoms of Sthaulya. The score of symptoms was assessed before and after the treatment and statistical analysis was undertaken.

Objective criteria for assessment: Apart from Body weight and B.M.I. as objective parameters, for the present study the girth measurements of certain regions using measuring tape before and after the treatment was also carried out. The girth measurement of following areas where generally the adiposity is found more was taken: -

1. Chest - In normal expansion at the level of nipple.

2. Abdomen - At the level of umbilicus

3. Hip - At the level of highest point of distension of buttock.

4. Mid-thigh - Mid of the thigh between pelvic and knee joints

5. Mid arm - Mid of the arm between shoulder joint and elbow joint.

Skin fold thickness: The effectiveness of the therapy was assessed by measuring the skin fold thickness (Anthropometrics) by Vernier callipers before and after treatment in some particular areas as the body like:

1. Skin fold of the middle portion of the biceps muscle

2. Skin fold of the middle portion of the triceps muscle

\section{Observations and Results:}

The demographic data of all the patients registered for the study is discussed on the basis of their age, sex, religion, occupation, marital status, socio economic status etc. Most of the patients who participated in the research study were belonging to the age group of 41 - 50 years $(66.66 \%)$ followed by $21-30$ years $(23.33 \%) ; 56.67 \%$ were females and remaining $43.33 \%$ were males; all the patients were belonging to Hindu religion (100\%); $66.67 \%$ of them were belong- 
ing to service class, whereas $26.67 \%$ were students; $33.33 \%$ were educated up to primary level, whereas $26.67 \%$ each were reported to study up to high school as well as graduates. As per the lifestyle distribution $73.33 \%$ of the patients in the present study were having moderately active lifestyle and $23.33 \%$ had sedentary lifestyle; $66.66 \%$ of the patients reported to have Mandagni and 30\% reported to have Vishamagni;

Distribution of 30 patients according to B.M.I.: Maximum $76.67 \%$ patients were having B.M.I in the range of $30-35 \mathrm{Kg} / \mathrm{M}^{2}$ while remaining $23.33 \%$ patients were having BMI in the range of $35-40 \mathrm{Kg} / \mathrm{M}^{2}$. None of the patients reported to have B.M.I. over 40 $\mathrm{Kg} / \mathrm{M}^{2}$.

Effect of therapy on haematological \& biochemical parameters: The mean initial $\mathrm{Hb}$. gm $\%$ was $12.36 \mathrm{gm}$ $\%$ which was decrease to $11.66 \mathrm{gm} \%$. The result is statistically insignificant $(\mathrm{P}<0.05)$. E.S.R. was 20.93 $\mathrm{mm}$ fall in one hour which was improved to $27.27 \mathrm{~mm}$ at one hour. However, the result was found to be statistically insignificant $(0<05)$. No apparent changes were observed in rest of haematological parameters. The result is statistically insignificant in all haematological parameters. No apparent changes were observed in biochemical investigations.

Effect of therapy on B.M.I. and Body Weight (Table 1): Reduction in weight was $3.03 \%$ and in B.M.I was $2.95 \%$, both the results were statistically highly significant $(<0.001)$.

Effect of therapy on body circumference (Table 2): Decrease observed in various body circumferences i.e. Abdominal circumference $3.22 \%$, Thigh circumferences $1.68 \%$, Chest circumference $1.55 \%$, Hip circumference $1.50 \%$, Calf circumference $1.34 \%$, Forearm circumference $1.03 \%$ and Arm circumference $0.10 \%$ were observed. In which Chest circumference, Abdomen circumference and Hip circumference were statistically highly significant $(\mathrm{P}<0.001)$. While in Calf circumference statistically significant $(\mathrm{P}<0.01)$, while in Arm circumference, Forearm circumference $\&$ Thigh circumference were statistically insignificant. Effect of therapy on skin fold thickness (Table 3): Reduction observed in various Skin fold thickness i.e.
Biceps $6.88 \%$, Triceps $5.67 \%$. Both the results were statistically highly significant.

Effect of therapy on symptoms of Sthaulya (Table 4): Relief in Daurgandhya was $85.71 \%$, Kshudra swasa was $60 \%$, Anga gauravta was $38.42 \%$, Ati kshudha was 5.49\%, Ati pipasa was $21.54 \%$, Utsaha hani was $43.75 \%$, Daurbalya was $50 \%$, Nidradhikya was $40.48 \%$, Snigdhagatrata was $42.86 \%$ and $A n$ gashaithilya was $36.36 \%$. Improvement in Daurgandhya, Ati kshudha, Utsaha hani, Daurbalya was statistically significant with $\mathrm{p}<0.05$. Improvement in Nidradhikya, Anga gauravta and Ati pipasa was highly significant statistically with $\mathrm{p}<0.01$. Result in other parameters could not be calculated as $t$ value was insignificant.

Overall effect of therapy (Table 5): Total 24 patients completed the study. Out of 24 patients, 10 patients gained mild improvement $(41.67 \%), 8$ patients moderate improvement $(33.33 \%)$ while 3 patients markedly improved (12.50\%) and remained 3 patients were found unchanged $(12.50 \%)$.

\section{DISCUSSION}

Of the total patients, 24 completed the trial for which treatment was observed according to plan of study. The results were derived after execution of statistical techniques. The effect of therapy has been presented as following:

Effect on Biochemical Parameters: In present study, Biochemical investigation viz. FBS, S. cholesterol, S. Triglyceride and HDL cholesterol were carried out before and after treatment. During the study maximum Biochemical Parameters before and after treatment were found within normal limits.

Effect of therapy on weight \& B.M.I.: Reduction in weight was $3.03 \%$ and in B.M.I was $2.95 \%$, both the results were statistically highly significant $(<0.001)$. The trial drug was effective in reducing the mean weight and BMI.

Effect of therapy on body circumference: Decrease observed in various body circumferences i.e. Abdominal circumference $3.22 \%$, Thigh circumferences $1.68 \%$, Chest circumference $1.55 \%$, Hip circumference $1.50 \%$, Calf circumference $1.34 \%$, Forearm 
circumference $1.03 \%$ and Arm circumference $0.10 \%$ were observed. In which Chest circumference, Abdomen circumference and Hip circumference were statistically highly significant $(\mathrm{P}<0.001)$. While in Calf circumference statistically significant $(\mathrm{P}<0.01)$, while in Arm circumference, Forearm circumference \& Thigh circumference were statistically insignificant.

Effect of therapy on skin fold thickness: Reduction observed in various Skin fold thickness i.e. Biceps $6.88 \%$, Triceps $5.67 \%$. Both the results were statistically highly significant.

Effect of therapy on symptoms of Sthaulya: Relief in Daurgandhya was 85.71, Kshudraswasa was $60 \%$, Angagauravta was $38.42 \%$, Atikshudha was $5.49 \%$, Atipipasa was $21.54 \%$, Utsahahani was $43.75 \%$, Daurbalya was 50\%, Nidradhikya was $40.48 \%$, Snigdhagatrata was $42.86 \%$ and Angashaithilya was 36.36\%. Improvement in Daurgandhya, Atikshudha, Utsahahani, Daurbalya was statistically significant with $\mathrm{p}<0.05$. Improvement in Nidradhikya, Angagauravta and Atipipasa was highly significant statistically with $\mathrm{p}<0.01$. Result in other parameters could not be calculated as $t$ value was insignificant. Thus, we may conclude that mostly combination of Katu-Ras, Laghu, Ruksha and Ushna-Virya, Pradhana drugs in Trikatu churna can do the function of Strotovibandha nashana and against Kapha, Kleda and Meda. These drugs may be effective on Rasa, Meda, Medodhatvagni, which provided good results in all signs and symptoms.

Overall effect of therapy: Total 24 patients completed the study. Out of 24 patients, 10 patients gained mild improvement $(41.67 \%), 8$ patients moderate improvement $(33.33 \%)$ while 3 patients markedly improved $(12.50 \%)$ and remained 3 patients were found unchanged (12.50\%).

Discussion on Effect: The disease Sthaulya originates due to consumption of Kapha Vriddhikara Ahara, Vihara and Manasa Nidana. These factors derange Jatharagni causing Ama Annarasa, which results in Medodhatvagni-mandya. This condition leads to the excessive growth and accumulation of Medodhatu, causing the disease Sthaulya.
Probable Mode of Action: Trikatu Churna encounters Vata \& Kapha Dosha by virtue of its Katu-Rasa dominance \& Ushna-Virya. Vatahara action is also achieved by Laghu and Snigdha property. Meda \& Kleda are the chief culprits in Sthaulya. Katu-Rasa performs Medo-Kledopa-Shoshana action. UshnaVirya also helps in Kleda and Meda Vilayana action. Katu-Rasa, Ushna-Virya encounters Dhatwagnimandya \& potentiates the weakened Dhatwagni and help in Amapachana thereby alleviates Aparipakwa and Ama dhatu. Due to Katu-Rasa, all the involved channels are dilated i.e. "Srotansi Vivrunoti" action. KatuRasa and Ushna-Virya check over Medovaha and Mamsavaha Srotodushti. In nutshell, in Trikatu churna, maximum ingredients have Katu Ras \& Laghu, Ruksha and Ushna Virya, Vata-Kaphashamak, Karshana, Lekhaniya, Medorogahara, Amapachana, Dhatu shoshana properties, which normalize the state of Agni. Thus, regulated Jatharagni, checked the excessive growth and accumulation of Medodhatu and thereby causing Lakshana Upashamana of disease Sthaulya. An important point is during the clinical study very interesting findings were found. Most of the female patients who have irregular menstruation were getting regular. This may be due to the Agni mahabhuta Pradhana (Su. Su.15/16) and Ushna Virya, Dipana, Pachana effects of Trikatu churna.

\section{CONCLUSION}

Sthaulya is a predominant metabolic disorder, which is described by Charaka in Ashtaunindita Purusha. Nidanas of Sthaulya mentioned in the classics are now changing. Increasing stress, faulty dietary habits and decreased awareness regarding exercise are becoming the prominent causative factors for Sthaulya. Based on the symptomatology, Sthaulya could be co-related to Obesity. An abnormal growth of adipose tissue due to an enlargement of fat cell size or an increase in fat cell number or both is called obesity. BMI between 25 and $29.9 \mathrm{~kg} / \mathrm{m}^{2}$ is called overweight and a BMI greater than $30 \mathrm{~kg} / \mathrm{m}^{2}$ is called obese. Intake of Trikatu churna for 30 days has positive results in relieving the symptoms of Sthaulya. 


\section{REFERENCES}

1. Ng M, Fleming T, Robinson M, Thomson B, Graetz N, Margono $\mathrm{C}$ et al; Global, regional and national prevalence of overweight and obesity in children and during 1980-2013; A systematic analysis for the Global Burden of Disease Study 2013; available from http://www.sciencedirect.com/science/article/pii/S0140 673614604608 (PubMed) as cited on

2. Stevens GA, Singh GM, La Y, Danaei G, Lin JK, Finucane $\mathrm{MM}$ et al; National, regional and Global trends in adult overweight and obesity prevalences; Popul Health Metr, 2012; 10(1); 22 (PubMed)

3. Kelly T, Yang W, Chen CS, Reynolds K, He J; Global burden of obesity in 2005 and projections to 2030; International Journal of Obesity; 2008 Sept; 32(9); 14311437; PubMed

4. Obesity and Overweight; WHO factsheets; https://www.who.int/en/news-room/factsheets/detail/obesity-and-overweight (as cited on 17.05.2020)

5. Dan L Longo, Anthony S Fauci, Dennis L Kasper, Stephen L Hauser, Larry J Jameson, Joseph Loscalzo, edi- tors. Harrisons Principles of Internal Medicine, Vol. 1. 18th ed. Place: McGraw Hill Education; 2011. p.631.

6. Dan L Longo, Anthony S Fauci, Dennis L Kasper, Stephen L Hauser, Larry J Jameson, Joseph Loscalzo, editors. Harrisons Principles of Internal Medicine, Vol. 1. 18th ed. Place: McGraw Hill Education; 2011. p.631.

7. Park K, editor. Park's Textbook of Preventive and Social Medicine. 24 ${ }^{\text {th }}$ ed. Banarsidas Bhanot Publishers; 2016. p.415-419.

8. Park K, editor. Park's Textbook of Preventive and Social Medicine. $24^{\text {th }}$ ed. Banarsidas Bhanot Publishers; 2016. p.415-419.

9. Charaka. Charaka Samhita (Ayurveda Dipika commentary of Chakrapanidatta). Yadavji Trikamji Acharya, editor. 5th ed. Varanasi: Chaukambha Sanskrit Sansthan; 2001. p.738, 117

10. Sushruta, Sushruta Samhita (Nibandha Sangraha of Dalhana); Yadavji Trikamji Acharya editor; $8^{\text {th }}$ edition; 2005; Varanasi, Chaukhambha Orientalia; p. 168

11. Sharangadhara, Sharangadhara Samhita; Shree Radhakrishna Parashar; $4^{\text {th }}$ edition, 1994; Shree Baidyanath Ayurveda Bhavan, Nagpur; p.249

Table 1: Effect of therapy on haematological \& biochemical parameters.

\begin{tabular}{|l|l|l|l|l|l|l|l|}
\hline Parameter & Mean & \%age Diff & S.D. & S.E. & 't' & P \\
\hline B.T. & A.T. & & & & & \\
\hline Hb $($ gm\%) & 12.36 & 11.66 & 5.66 & 0.94 & 0.24 & 2.90 & $<0.05$ \\
\hline ESR & 20.93 & 27.27 & 30.25 & 10.77 & 2.78 & 2.28 & $<0.05$ \\
\hline FBS & 94.93 & 95.40 & 0.49 & 12.11 & 3.13 & 0.15 & - \\
\hline S. Cholesterol & 179.93 & 174.4 & 3.08 & 14.57 & 3.76 & 1.47 & - \\
\hline S. Trigylceride & 129.6 & 116.13 & 10.39 & 40.77 & 10.53 & 1.28 & - \\
\hline S.HDL & 40.87 & 41.13 & 0.65 & 6.66 & 1.72 & 0.16 & - \\
\hline
\end{tabular}

Table 2: Effect of therapy on B.M.I. and Body Weight

\begin{tabular}{|l|l|l|l|l|l|l|l|}
\hline \multirow{2}{*}{ Parameter } & Mean & \%age Diff & S.D. & S.E. & 't' & P \\
\cline { 1 - 8 } & B.T. & A.T. & & & & & \\
\hline Weight (in kg) & 78.38 & 76 & 3.03 & 1.13 & 0.23 & 10.25 & $<0.001$ \\
\hline B.M.I. $\left(\mathrm{Kg} / \mathrm{M}^{2}\right.$ ) & 31.45 & 30.52 & 2.95 & 0.4 & -0.08 & 11.44 & $<0.001$ \\
\hline
\end{tabular}

Table 3: Effect of therapy on body circumference

\begin{tabular}{|l|l|l|l|l|l|l|l|}
\hline Parameter & Mean & \%age Diff & S.D. & S.E. & 't' & P \\
\cline { 2 - 8 } & B.T. & A.T. & & & & & \\
\hline Abdomen & 101.77 & 101.18 & 1.55 & 1.93 & 0.35 & 4.58 & $<0.001$ \\
\hline Hip & 98.04 & 94.88 & 3.22 & 4.27 & 0.77 & 4.11 & $<0.001$ \\
\hline Thigh & 114.07 & 112.36 & 1.50 & 1.87 & 0.34 & 5.09 & $<0.001$ \\
\hline Calf & 55.09 & 54.16 & 1.68 & 2.65 & 0.48 & 1.94 & $>0.05$ \\
\hline Arm & 40.31 & 39.77 & 1.34 & 1041 & 0.25 & 2.14 & $<0.01$ \\
\hline Forearm & 32.07 & 32.04 & 0.10 & 0.95 & 0.17 & 0.19 & $>0.05$ \\
\hline
\end{tabular}


Table 4: Effect of therapy on skin fold thickness.

\begin{tabular}{|l|l|l|l|l|l|l|l|}
\hline \multirow{2}{*}{ Parameter } & \multicolumn{2}{|l|}{ Mean } & \%age Diff & S.D. & S.E. & 't' & P \\
\cline { 1 - 9 } & B.T. & A.T. & & & & & \\
\hline Biceps (cms) & 2.24 & 2.09 & 6.88 & 0.09 & 0.02 & 8.11 & $<0.001$ \\
\hline Triceps (cms) & 2.94 & 2.78 & 5.67 & 0.09 & 0.02 & 8.91 & $<0.001$ \\
\hline
\end{tabular}

Table 5: Effect of therapy on symptoms of Sthaulya

\begin{tabular}{|l|l|l|l|l|l|l|l|}
\hline \multirow{2}{*}{ Parameter } & \multicolumn{2}{|l|}{ Mean } & \%age Diff & S.D. & S.E. & 't' & P \\
\hline B.T. & A.T. & & & & & \\
\hline Daurgandhya & 0.58 & 0.08 & 85.71 & 0.59 & 0.17 & 2.94 & $<0.05$ \\
\hline Kshudra swasa & 0.21 & 0.08 & 60 & 0.34 & 0.17 & 0.74 & - \\
\hline Anga gauravta & 1.08 & 0.67 & 38.42 & 0.58 & 0.13 & 3.27 & $<0.01$ \\
\hline Ati kshudha & 3.79 & 4 & 5.49 & 0.41 & 0.84 & 2.46 & $<0.05$ \\
\hline Chala sphika-udara-stana & 2.71 & 3.29 & 21.54 & 0.58 & 0.12 & 4.90 & $<0.001$ \\
\hline Utsaha hani & 2.16 & 2.16 & - & - & - & - & - \\
\hline Daurbalya & 0.84 & 0.47 & 43.75 & 0.49 & 0.11 & 3.24 & $<0.05$ \\
\hline Nidradhikya & 0.75 & 0.38 & 50 & 0.58 & 0.17 & 2.26 & $<0.05$ \\
\hline Snigdhagatrata & 1.75 & 1.04 & 40.48 & 0.81 & 0.19 & 3.73 & $<.001$ \\
\hline Anga shaithilya & 0.29 & 0.17 & 42.86 & 0.34 & 0.14 & 0.90 & - \\
\hline
\end{tabular}

\section{Source of Support: Nil \\ Conflict of Interest: None Declared}

How to cite this URL: Ankur Saxena et al: A Clinical Study On The Management Of Sthaulya By Trikatu Churna. International Ayurvedic Medical Journal \{online\} 2020 \{cited July, 2020\} Available from: http://www.iamj.in/posts/images/upload/2382_2388.pdf 